Article

\title{
Living Labs in University-Industry Cooperation as a Part of Innovation Ecosystem: Case Study of South Korea
}

\author{
Olga A. Shvetsova $(\mathbb{D}$ and Sang-Kon Lee * \\ School of Industrial Management, Korea University of Technology and Education (KOREATECH), \\ Cheonan-si 31254, Korea; shvetsova@koreatech.ac.kr \\ * Correspondence: sklee@koreatech.ac.kr
}

Citation: Shvetsova, O.A.; Lee, S.-K. Living Labs in University-Industry Cooperation as a Part of Innovation Ecosystem: Case Study of South Korea. Sustainability 2021, 13, 5793. https://doi.org/10.3390/su13115793

Academic Editor: Antonio

Messeni Petruzzelli

Received: 22 March 2021

Accepted: 2 May 2021

Published: 21 May 2021

Publisher's Note: MDPI stays neutral with regard to jurisdictional claims in published maps and institutional affiliations.

Copyright: (c) 2021 by the authors. Licensee MDPI, Basel, Switzerland. This article is an open access article distributed under the terms and conditions of the Creative Commons Attribution (CC BY) license (https:// creativecommons.org/licenses/by/ $4.0 /)$.

\begin{abstract}
Living labs are an extremely attractive opportunity for Korean companies to enhance collaborative research and transform development activities targeting the complexity of today's economic changes. However, although there is plenty of technological support for collaboration, Korean companies still lack clear understanding how to improve business processes in the living lab ecosystem. The main problem is that the development of living labs in Korea is in the early stages due to the significant market regulation system and the gap between the innovation system and market regulation. The purpose of this study was to investigate the influence of living labs on the innovation ecosystem of South Korea, therefore the research is focused on the innovation process within university-industry cooperation. The focus is on the structures, objectives, and drivers of the collaborative innovation ecosystem and elements of living labs. The expert method was applied and the interviews were arranged with 30 executives of high-tech start-up domestic projects; the main hypothesis was that different elements of living labs have direct and positive impacts on the development of the innovation ecosystem; additionally. A case study of the local university-industry environment was conducted, and the evaluation showed that there is a positive correlation innovation networks and living lab structures.
\end{abstract}

Keywords: university-industry cooperation; living laboratory; South Korea; innovation ecosystem; open innovation

\section{Introduction}

The industrial revolution and active investment in telecommunications systems have made South Korea the second largest country in the world in the field of advanced innovative technologies, after the United States of America [1]. Moreover, the country has won about $50 \%$ of the world market (consumers) of shipbuilding products; it is the largest manufacturer of electronics (Samsung), and the world's fifth highest in car manufacturing (Hyundai) [2]. However, nowadays there are many rapid changes in the external environment that require fast feedback from Korean market players; for the Korean government, business, and society, these changes lead to questions on how to maintain competitiveness and implement appropriate transformation processes (including Living Lab (LL) landscape) into the national innovation ecosystem.

In Europe, Living Lab activities are concentrated on real-life related fields such as safety, residence, traffic, environment or welfare and so on. This implies that Living Lab well corresponds to the objective of "Local problem solving" and "Local residence or user oriented" [1,2]. Unlike other innovative models, Living Lab has information technologybased cooperation, user participation and private partnership which enables to counteract to solve local problems seamlessly. It also focuses on solving problems that are closely related with everyday life, which therefore is in line with justification of securing local capability. Since Living Lab was introduced in Korea, interests have been increased and attempts from various aspects have been made. Up until now, however, they have rather 
focused on experimenting development process by users' participation and therefore Living Lab projects that deal with real-life problems seem insufficient.

Geiger and Ca [3] put forward the thesis that the fourth industrial revolution (Industry 4.0) is directly related to innovation, individual creativity, smart technology, and the protection of individual intellectual property rights. Brignolfson and McAfe [4] and Tyler and Hansen [5] confirmed the need to recognize the equivalence of contributions to the development of innovation at the system level and by individual members of society. In an age with an economy based on knowledge and a digital revolution, the behavior and creative thinking of individuals in an organization are necessary elements for creating new technological capabilities and developing alternative business models and solutions. This thesis finds a response to the problem in South Korea in the context of the fourth industrial revolution, which was given that name in 2011 in Germany and developed in Europe as a set of concepts of smart systems, smart industries, and digital economy. The fourth industrial revolution is not coming only through technological progress; transformations are also taking place at the fundamental sociocultural level. South Korea has to find a way to promote successful interactions among three elements of government, business, and universities to develop sources and stimuli for individual creative ideas [6,7]. Seong et al. in 2016 [8] suggested that there are three original features of living labs in South Korea:

1. First, each case tends to link science technology and information and communication technology with local problem solving, though there is a difference between the technologies used.

2. Second, local residents play a leading role in the whole living lab process from problem identification to technical experimentation, diffusion, and application.

3. Third, intermediaries commonly play an important role in the operation of living labs. There are several problems with the living lab management system in South Korea:

- The problem recognized in the Korean innovation system is how to improve some advanced skills and elements of them (for example, flexibility, adaptability, and creativity), which is helpful for current crisis overlap within economic development.

- The ecosystem description was used some time ago to suggest that market participants are not just competing, but rather motivated to seek the benefits of sharing resources, networks, transfers, and ideas. By bringing together market participants such as companies, business incubators, and industrial clusters, they seek to create synergies that enhance the innovation environment.

- Start-up incubators drive market demand by focusing on the needs of tech entrepreneurs. Some incubators operate as autonomous ecosystems, but often the creation of an infrastructure, that is, a city, a region, or even an entire country, is required to effectively create an innovation ecosystem [8].

In the field of cooperation between the public and private sectors, South Korea is at the top of global trends and has a comparatively good research and development (R\&D) investment with a ratio of $4.55 \%$ to gross domestic product (GDP) [9]. The public sector in plays an active role in promoting start-ups and implements a number of programs in collaboration with central and local governments. A common characteristic for many government programs is close collaboration with the private sector. For example, the Korean market has the Accelerator Investment-Driven Tech Incubator Program for Startups (TIPS), a long-term initiative that provides funding for start-ups to enter incubators and accelerators operated by private investors such as KB Investment and Hyundai Motor Group. Another form of major cooperation between business and government is the Centres for Creative Economy and Innovation (CCEI), created several years ago. In total, there were 19 such centers in South Korea in 2019, each working with the joint support of regional governments and one of the Korean conglomerates (global corporations), such as Samsung, LG, or SK [9].

While sectoral and industrial integration plays an important role in stimulating startups in this country, maintaining and expanding new start-ups requires further action. 
Several years ago, the South Korean government launched the national strategy of the Fourth Industrial Revolution, which considered its national interests, characteristics, and traditions (Figure 1). The central feature of this market-political plan is the promotion of start-ups. In particular, the government is working to introduce regulatory development zones. So far, seven cities and regions have been identified as regulatory development zones in their respective industries, from healthcare to safety. For example, the southern city of Busan is becoming a hub for blockchain regulatory experiments and smart city innovation.

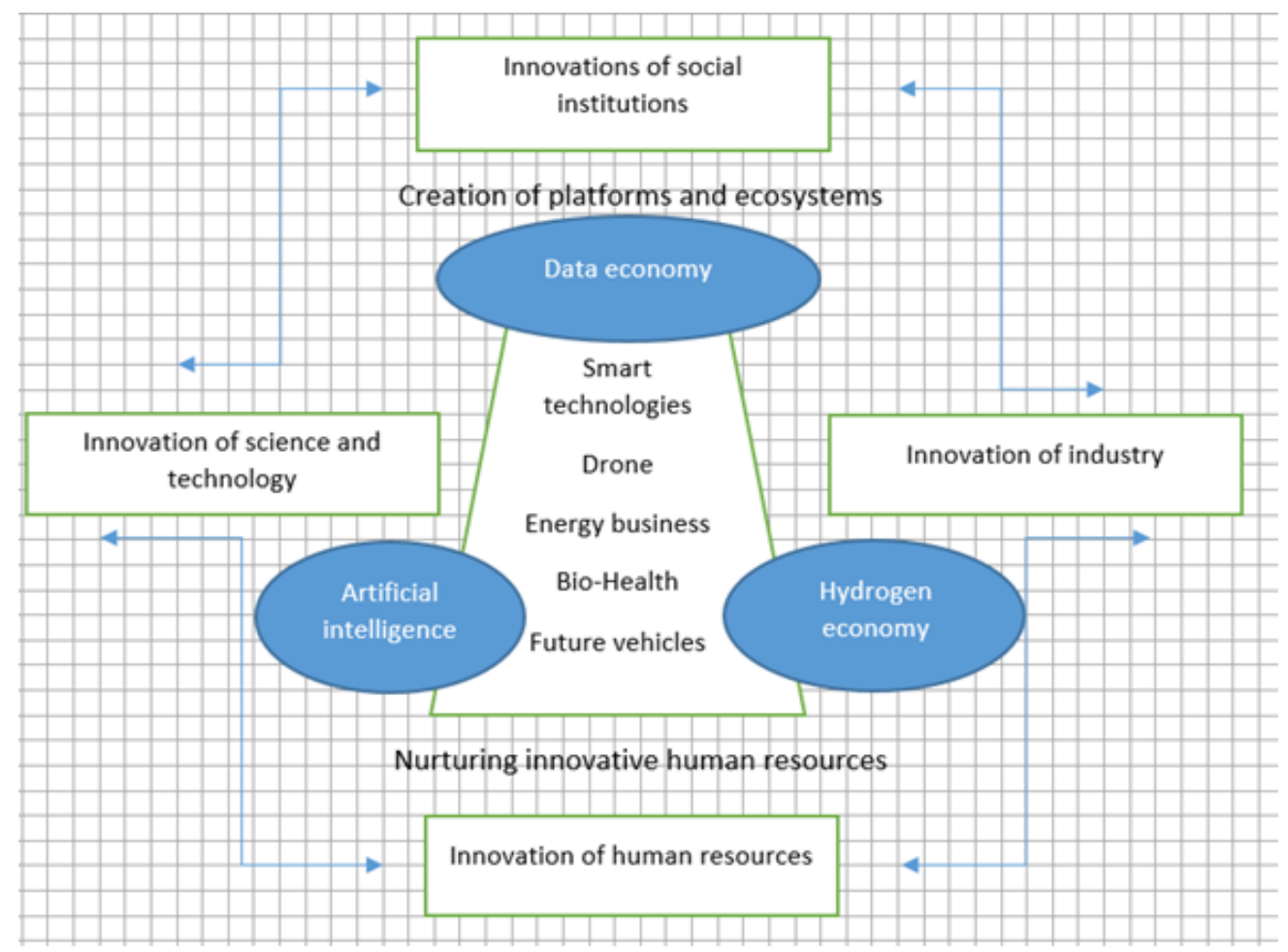

Figure 1. Innovation ecosystem in South Korea. Innovations of social institutions = Government regulations; smart technologies $/$ drone $/$ etc. $=$ start-up projects. Source: made by authors .

Despite increased government measures to distribute innovation and entrepreneurship throughout the region, a significant proportion of start-ups remain in the metropolitan area of Seoul and neighboring Gyeonggi province. The surrounding provinces are home to a growing cluster of new and established technology companies. According to the Seoul Startup Hub, as of March 2019, 154 accelerators were registered in South Korea, of which 100 were in Seoul. There is also another national feature of the development of the country's innovation ecosystem: many of the top-ranked universities are located in the capital, making it a source of talent and a greenhouse for research and innovation programs. The Seoul Metropolitan Government provides prospective entrepreneurs with access to a wide range of local support services, including 24 incubators, 6 innovation development sites, and 10 startup information centers [9].

The Korean innovation market has its own distinctive features. For example, it is a well-known fact that good infrastructure lays the foundation for a vibrant ecosystem. However, for the ecosystem to provide synergy, it is necessary to develop highly effective communication between participants and participating organizations. South Korea has emerged as a contender for global competition through rapid growth and innovation, but has not yet fully grasped the potential of local start-ups. Statistics prove this: it ranks only twenty 24th out of 137 countries in the Global Entrepreneurship Index [9].

The following difficulties are found for start-ups to successfully develop and launch new products/services [10]. 
1. They lack its own capability to plan products and services that reflect target markets and customer needs on its own.

2. Compared to big companies, it is difficult to gain consumer confidence and improve satisfaction because the accumulation of data on consumer experience is insufficient.

3. Even after product and service development, it is difficult to obtain certification, so there are many cases of failure to market.

In order to solve these problems of start-ups, Living Lab is in the spotlight as a platform to support efficient innovation activities.

To improve the environment for the development of local start-ups, it is necessary to introduce measures to improve the structure of the innovation system; this is fully facilitated by the development of living labs.

The authors discuss the Korean market with domestic innovation ecosystem in this study. There are three main partners in the innovation ecosystem of Korea: government, university, and business. Each member plays a role: universities focus on research and development, companies are responsible for market demand, and the government controls quality and competence.

There are many hubs, business incubators, and accelerators in Korea, including those with active government support. The list of key players also includes local giants such as Samsung, LG, Hyundai, and others, creating their own hubs and pursuing a policy of active support for start-ups. However, they have a purely applied interest. The most promising young companies are formed with the aim of further absorbing and strengthening the main company [10].

On the other hand, in South Korea, it is believed that promoting innovation in the economy is the responsibility of large corporations, as is maintaining the country's current growth rate.

An atmosphere of great hope and expectation has been created around existing and newly created start-ups. It is believed that they will create the necessary impetus and a new wave of development of Korean industry, and act as full-fledged partners to and possible back-ups for large corporations that currently hold power in the economy.

This study contributes to the Living Lab research area in several ways. Firstly, it unpacks the recent evolution of Living Labs studies and places them in the broader context of innovation management research. Secondly, it analyses the collaborative relationships linking elements of Living lab and elements of innovation ecosystem and identifies a practical example of Korean economy case study. Thirdly, it discusses the problem topics characterizing the field in the context of Korean business environment. Finally, by looking at further research citing the Living Lab literature, this study maps influence and potential development of current research. Following this introduction to the Living Lab phenomenon and its relevance in innovation ecosystem, the second section of this paper discusses the diverse nature of the Living Lab field with its influence on innovation ecosystem within university-industry cooperation. The third section describes the sample selection case study of Living lab in Korean market as well as the expert and interview methods used to advance authors' understanding of the Living Lab debate in innovation ecosystem. The findings are presented in three subsections (i) analyzing the elements of Living Lab, (ii) examining the current Living Lab case study in South Korea, and (iii) revealing the influence of Living Lab on innovation ecosystem development. To conclude, the theoretical contributions as well as the managerial implications of this study are discussed. Finally, the study's limitations and future research directions are outlined.

\section{Literature Review}

\subsection{Innovative Ecosystem Features}

One of the first researchers to apply the term "ecosystem" in relation to economics was Rothschild (1990) [10]. The sense the term consisted in shifting the emphasis on the interactions between the participants in the system: how alive the organism is determined by genes, and its position in the supply chain and organization is determined by its place in 
the network of customers, competitors, partners, and suppliers, and the level of technology and innovation on which the success of the action depends is based on the organizations in this environment. Another definition was formulated by Morrar et al. in 2017:" An innovation ecosystem refers to a loosely interconnected network of companies and other entities that coevolve capabilities around a shared set of technologies, knowledge, or skills, and work cooperatively and competitively to develop new products and services" [11].

The authors consider the commercialization of innovation as a holistic process or thread with a specific purpose (conducting transactions) and flowing through the elements (resources and connections), united into a single and innovative ecosystem. From this point of view, definitions of the basic elements of the theory are given in Figure 2.

\begin{tabular}{|c|c|c|}
\hline \multirow[t]{3}{*}{\begin{tabular}{|l|} 
Innovation - an \\
idea, development, \\
or competence \\
brought to a deal. \\
\end{tabular}} & & \\
\hline & $\begin{array}{l}\text { Commercialization of innovation - a single } \\
\text { process of converting the flow of ideas, } \\
\text { developments or } \\
\text { competencies into assets in project formats with } \\
\text { subsequent transactions for the sale of created }\end{array}$ & \\
\hline & & $\begin{array}{l}\text { Innovative ecosystem - aggregate } \\
\text { subjects interacting in the process of commercialization of } \\
\text { innovations and their interconnections, } \\
\text { accumulating human, financial and } \\
\text { other resources for intensification, optimization } \\
\text { and ensuring the effectiveness of the commercialization of } \\
\text { innovations. }\end{array}$ \\
\hline
\end{tabular}

Figure 2. Main definitions of innovative system. Adapted from source: Buhr et al. [12], Friesen [13], Compagnucci et al. [14].

From the above definition, four main dimensions of the innovation ecosystem follow:

1. Purposeful process: an innovation ecosystem is built around a process of commercialization of innovations, which has a clear result in the form of the output of products on market.

2. Subjects interact in the process of commercialization of innovation.

3. There are connections between them.

4. There is an environment that provides resources for the subjects of commercialization of innovation.

However, to date, there is no clear integration of the concept of LLs in the innovation ecosystem literature stream. Most of the open innovation literature focusses on the acquisition of knowledge from external sources by firms, often in a business-to-business context, whereas LLs operate through public-private-people partnerships [15].

A successful innovation ecosystem aims to commercialize innovation. Therefore, the key performance indicators are as follows:

1. Commercial results in the form of transactions in three main forms: customization, research and development, and intellectual property rights (licensing).

2. A consistent, unbreakable transformation of an idea into a deal: a stream of input ideas, developments, and competencies of team members, converted into assets that are then sold. It is important to understand that the ideas themselves and the teams are not assets. Thus, resources can be sold on the market only when they have passed the stage of transformation into commercial projects with specific assets $[14,15]$.

3. The subjects are relevant specialists united in interaction networks, thereby ensuring continuity in the process of commercializing innovations.

4. A suitable environment for commercialization. Such an environment could do the following:

- Stimulate active interactions with subjects of the commercialization process by promoting innovations, forming networks of interaction, and holding events. 
- Use formal (laws, regulations) and informal (culture) institutions to stimulate the commercialization of innovations and minimize possible losses arising when interacting with the environment.

- Have sufficient financial and infrastructural resources to organize the process of innovation commercialization.

- Generate self-organization processes and self-development of its elements, leading to decreased transactional costs within the system [14,15].

Living Labs research not only informs practice, but it is also regularly driven by people directly involved in innovation projects. In their review of the early days of Living Labs, Leminen and Westerlund [15] discussed the key roles of certain researching and practicing individuals in the establishment of Living Labs in the United States and Europe. Indeed, boundaries between Living Labs research and practice can be blurred and intertwined. For example, prominent Living Labs scholars such as Dimitri Schuurman not only publish articles on the topic, but also manage innovation projects and develop specific Living Labs offerings targeted at entrepreneurs [16].

The innovation ecosystem concept was proposed by Wessner in 2015 [17] and offers a tool for creating conditions that increase the competitiveness of organizations in national and regional economies. The central concept is the idea of innovation as a process of transforming an idea into a marketable product or service, which requires the collective efforts of participants: companies, universities, research companies, venture funds, and the like. An innovation ecosystem formalizes these efforts by enabling the achievement of a synergistic effect.

\subsection{University-Industry Cooperation and Its Impact on Living Lab}

Living Lab as a term technically means 'Laboratory of everyday life', which stemmed from observing a certain user through IoT censor installed within the user's living space $[15,16]$. Living Lab is a real-life setting laboratory where user and producer together can create an innovation and is a platform on which active interactions are made between innovative subjects as a model of open-form reformation network $[17,18]$. The participants are composed of R\&D researcher, company, authority and end-user, etc. and they share the common objective and cooperate. Above all, the main characteristic is that Living Lab actively takes local residents into consideration and that local community plays a supportive role as a facilitator or enabler of Living Lab along with administrative organization. Living Lab has its significance in having suggested possibility of social reformation model that contributes to solving social problems by utilizing participation of end-user or local residents, cooperation of diverse parties, study activities that corresponds with actual life environment and scientific technology. Another distinct character of Living Lab is that it is user-oriented and covers comprehensive interaction between users, developers and diverse related parties and that it can be applied to various field, which in other words is different from existing test bed, a linear innovation model that focuses on technology developers.

Long-term international experience shows that cooperation between universities and industry can be important in the development of modern technological production within Living Lab landscape $[17,18]$. The components of such cooperation are the same in many countries, are tested for practical feasibility, are quite diverse, and usually include the following:

- Joint R\&D projects between industry and universities

- Specialized training programs carried out by universities for enterprises (mainly in new or rapidly developing areas)

- A wide range of activities carried out within the framework of so-called complex agreements between universities and enterprises. In this case, tasks related to both the targeted training of specialists for the enterprise and the solution of engineering and technological problems by the joint efforts of both parties are solved simultaneously.

- A range of consulting services provided by university staff for industrial companies. 
- Innovation, start-ups, and individual jobs carried out for industrial enterprises through university incubators and technology parks.

This concept of direct cooperation between universities and companies has been largely defined for decades and is famous in South Korea [18]. There are more benefits than disadvantages in university-industry cooperation for start-up development, and the authors mentions some benefits and risks according to the main area of the project's investigation (Table 1).

Table 1. Benefits and risks of university-industry cooperation as part of an innovation ecosystem.

\begin{tabular}{|c|c|c|c|c|}
\hline $\begin{array}{l}\text { Area of Investigation } \\
\text { (Element of } \\
\text { Innovation Ecosystem) }\end{array}$ & Benefits & Risks & Examples & Role of LL \\
\hline Infrastructure & $\begin{array}{l}\text { Cost reduction, } \\
\text { specialization, } \\
\text { concentration }\end{array}$ & $\begin{array}{l}\text { Less control, } \\
\text { dependence on } \\
\text { facility's owner }\end{array}$ & $\begin{array}{l}\text { Benefit: Specialization and } \\
\text { concentration on project's task; } \\
\text { possible to reduce costs } \\
\text { due to local placement } \\
\text { Risk: Not every partner will arrange } \\
\text { control over the project; strong } \\
\text { dependence on owner of } \\
\text { infrastructure (lab, factory) }\end{array}$ & Development \\
\hline Innovation transfer & $\begin{array}{l}\text { Rapid growth } \\
\text { and delivery of } \\
\text { innovations }\end{array}$ & $\begin{array}{l}\text { Competition, } \\
\text { quality of } \\
\text { service/product }\end{array}$ & $\begin{array}{l}\text { Benefit: Creation of innovations may } \\
\text { lead industry and university to new } \\
\text { forms and methods of production and } \\
\text { technology development, which can } \\
\text { be more flexible and market-oriented. } \\
\text { Partners may invent new strategies for } \\
\text { franchising or licensing. Fewer entry } \\
\text { barriers for new start-ups } \\
\text { and small enterprises } \\
\text { Risk: New innovations should be } \\
\text { focused on market needs and industry } \\
\text { standards, otherwise they will not be } \\
\text { successful. Innovations should } \\
\text { provide relevant quality of } \\
\text { product/service }\end{array}$ & IP \\
\hline Competence development & $\begin{array}{c}\text { Knowledge, skills, } \\
\text { and talent } \\
\text { development }\end{array}$ & $\begin{array}{l}\text { Competence } \\
\text { assessment; } \\
\text { matching indus- } \\
\text { try's/university's } \\
\text { standards }\end{array}$ & $\begin{array}{l}\text { Benefit: Relevant competencies create } \\
\text { new standards and skills, and new } \\
\text { methods of start-up development are } \\
\text { formulated; they help to implement } \\
\text { competitive strategies } \\
\text { for commercialization } \\
\text { Risk: Competence model has some } \\
\text { limitations: it must follow innovative } \\
\text { system requirements; it should } \\
\text { provide relevant impact for project's } \\
\text { developers and promoters }\end{array}$ & Training \\
\hline Knowledge protection & $\begin{array}{l}\text { Cooperation and } \\
\text { brand expansion }\end{array}$ & $\begin{array}{l}\text { Risks related to } \\
\text { intellectual } \\
\text { property } \\
\text { and rights }\end{array}$ & $\begin{array}{l}\text { Benefit: Participants may expand } \\
\text { brand and improve } \\
\text { positioning strategy } \\
\text { Risk: Most start-ups enter fast-cycle } \\
\text { markets, so competition may rise very } \\
\text { fast; it is necessary to protect } \\
\text { know-how and innovations and } \\
\text { arrange intellectual property rights } \\
\text { within collaboration }\end{array}$ & IP \\
\hline
\end{tabular}


Table 1. Cont.

\begin{tabular}{cccc}
\hline $\begin{array}{c}\text { Area of Investigation } \\
\text { (Element of } \\
\text { Innovation Ecosystem) }\end{array}$ & Benefits & Risks & Examples \\
\hline Customization & $\begin{array}{c}\text { New customers } \\
\text { and profit; } \\
\text { market expansion }\end{array}$ & $\begin{array}{c}\text { Unstable market } \\
\text { preferences (risk } \\
\text { of customization); } \\
\text { threats to health }\end{array}$ & $\begin{array}{c}\text { Benefit: University expands strategy } \\
\text { (even global), finds new markets, } \\
\text { becomes more attractive } \\
\text { to new customers } \\
\text { Risk: Customer preferences are } \\
\text { changeable, especially in different } \\
\text { markets, so it is necessary to provide } \\
\text { differentiation strategy }\end{array}$ \\
\hline
\end{tabular}

Source: made by authors (considerations were made upon high-tech projects' area in South Korea in 2017-2020).

However, the main problem of understanding of Living Lab's importance in Korean economy is that the implementation of these national tasks was the decision to create a network of research, innovation, and educational centers to conduct distributed research for the needs of industry and the economy at the request of the government. Separate orders in the interests of the state are formulated as research projects or grants and can be implemented by one or several members of the network, depending on the direction and volume of research. The main task for the network participants is to develop proposals and technological innovations in various fields of science, technology, and economics to solve both national and highly specialized tasks. But there is gap between the innovation system and market regulation [18].

However, in the last 10 to 15 years, the Korean government revealed, almost simultaneously, the problem of a serious gap between the cutting edge of scientific research (the academic community) and the level of technological development of the real industrial sector at the national level [19]. So, it is necessary to investigate how to improve the innovation system.

\subsection{Role of Living Labs in Innovation Ecosystem}

A living laboratory (LL) is an infrastructure project based on the systematic involvement of users in an innovative process in real-life conditions [20]. It is based on open innovation. Open innovation allows the use of not only a company's internal sources, but also its external sources. Competent people from the outside (other spheres) who are involved in the process offer ideas and give qualified advice, and thus contribute to the improvement of the final product. As a result, open innovation markets are emerging based on networked organizational structures [21]. Although, there is no consensus on the definition of the living lab to date, multi-stakeholder collaboration and end user involvement are the core elements of a living lab approach [21,22].

Multi-stakeholder collaboration in living lab projects is considered a requirement for innovation $[23,24]$ and is often brought forward using innovation frameworks, such as triple-, quadruple-, or quintuple-helix models (e.g., [25]).

The triple helix model of innovation refers to a set of interactions between academia (universities), industry, and government to foster economic and social development, as described in concepts such as the knowledge economy and knowledge society [26-28]. In innovation helical framework theory, each sector is represented by a circle (helix), with overlapping interactions shown. The initial modelling has advanced from two dimensions to show more complex interactions, for example, over time. The framework was first theorized by Henry Etzkowitz and Loet Leydesdorff in the 1990s, with the publication of "The Triple Helix-University-Industry-Government Relations: A Laboratory for Knowledge-Based Economic Development" [29,30]. Interactions between universities, industries, and governments have given rise to new intermediary institutions, such as technology transfer offices and science parks. Etzkowitz and Ledersdorff theorized the relationship between the three sectors and described the emergence of these new hybrid 
organizations [30]. The triple helix innovation framework has been widely adopted and, as applied by policy-makers, has contributed to the transformation of each sector (Figure 3).

Triple Helix Innovation Model

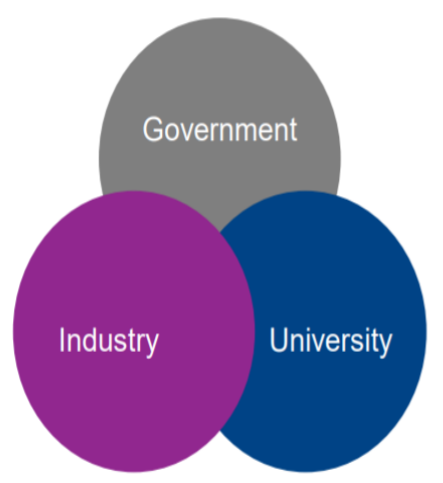

\section{Quadruple Helix Innovation Model}

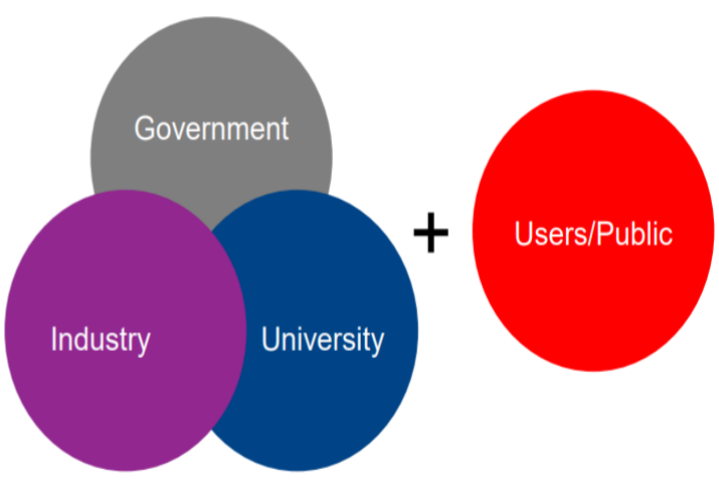

Figure 3. Types of innovation model. Adapted from source: Galvao et al. [29], Leydesdorff [30].

The triple helix model has also been applied to developing countries and regions. The same happens in South Korea, where Triple Helix Model helps to develop new strategies of government innovative Policy.

Building on the triple helix model, the quadruple helix model adds a fourth component to the framework of interactions between university, industry, and government: the public, consisting of civil society and the media [31-33]. It was first suggested in 2016 by Elias G. Carayannis and David F.J. Campbell [34].

The components of a living lab and its role in the innovation ecosystem are presented in Table 2.

Table 2. Components of living lab. ICT, information and communication technology.

\begin{tabular}{|c|c|c|c|}
\hline Living Lab Set-Up Phase & Components of Living Lab & $\begin{array}{c}\text { Role in } \\
\text { Innovation Ecosystem }\end{array}$ & Participants/Stakeholders \\
\hline $\begin{array}{c}\text { Formation of } \\
\text { community of developers }\end{array}$ & ICT + infrastructure & Cooperation & $\begin{array}{l}\text { Business/academia/ } \\
\text { research centers }\end{array}$ \\
\hline Formation of stakeholders & Partners & Resources & Government organizations \\
\hline $\begin{array}{l}\text { Formation of community of } \\
\text { professionals and experts }\end{array}$ & Partners + users & Collaboration & $\begin{array}{l}\text { Research and consulting } \\
\text { centers/government organiza- } \\
\text { tions/academia/business }\end{array}$ \\
\hline $\begin{array}{c}\text { Formation of community of } \\
\text { users (customers } \\
\text { and providers) }\end{array}$ & Users + research & Market development & Business \\
\hline Organization design & Methodology & Control & Business/academia/government \\
\hline IT platform implementation & Innovations & Knowledge + data transfer & Research centers/academia \\
\hline $\begin{array}{c}\text { Living lab } \\
\text { model development }\end{array}$ & Users + management & Innovation extension & Business/academia \\
\hline
\end{tabular}

Source: made by authors.

The South Korean government has developed a policy that was named National Innovation Cluster (NIC) [35]. NIC management is planned to be carried out by the agency Korea Institute for Advancement of Technology (KIAT) and the Ministry of Trade, Industry, and Energy (MOTIE) [36]. The purpose of the NIC is to implement policies to promote innovation and development of new types of industry. Within the NIC the organization of two types of clusters is planned: 
1. Research type to support large-scale demonstration projects in new industries and for business model commercialization.

2. Non-exploratory type at the city and provincial level to support the creation of associations.

Most of the recent authors who discuss the Living Lab environment in Asian region have specific understanding of Living Lab roles in high-tech market (Table 3).

Table 3. Literature review.

\begin{tabular}{|c|c|c|c|c|}
\hline Authors & Paper Title & Area of Investigation & $\begin{array}{l}\text { Contribution } \\
\text { in Literature }\end{array}$ & $\begin{array}{l}\text { Recognized Problem } \\
\text { (or Research Question) }\end{array}$ \\
\hline $\begin{array}{l}\text { Han J. and } \\
\text { Kim K. (2015) }\end{array}$ & $\begin{array}{l}\text { Enhancing Innovation } \\
\text { Platform: Bitgaram } \\
\text { Innocity Gwangju } \\
\text { Using ICT in Korea }\end{array}$ & $\begin{array}{l}\text { Innovation Lab, } \\
\text { Incubation center } \\
\text { and Smart City }\end{array}$ & $\begin{array}{l}\text { Self-sufficiently leading } \\
\text { process for the } \\
\text { regional development, } \\
\text { knowledge production } \\
\text { and innovation through } \\
\text { networking among the } \\
\text { heterogeneous actors; } \\
\text { presenting Living Lab } \\
\text { model as a platform for } \\
\text { communication using } \\
\text { ICT for the construction } \\
\text { of Energy Valley }\end{array}$ & $\begin{array}{l}\text { Proposes-using } \\
\text { business incubation } \\
\text { centers as the core of } \\
\text { the platform to } \\
\text { understand whether } \\
\text { various innovation } \\
\text { activities can be } \\
\text { spontaneously } \\
\text { generated. }\end{array}$ \\
\hline Cho E. (2018) & $\begin{array}{l}\text { Transforming a } \\
\text { Neighborhood into a } \\
\text { Living Laboratory for } \\
\text { Ur-ban Social } \\
\text { Innovation: A } \\
\text { Comparative Case } \\
\text { Study of Urban } \\
\text { Living Labs }\end{array}$ & $\begin{array}{l}\text { Living Lab } \\
\text { for Social innovation }\end{array}$ & $\begin{array}{c}\text { Foster urban } \\
\text { innovations by } \\
\text { bringing various } \\
\text { stakeholders, ranging } \\
\text { from local governments } \\
\text { to citizens, together to } \\
\text { co-create innovation }\end{array}$ & $\begin{array}{l}\text { What are the ways } \\
\text { Urban Living Labs } \\
\text { operate and contribute } \\
\text { to fostering urban } \\
\text { social innovation? }\end{array}$ \\
\hline $\begin{array}{c}\text { Kim Y., Lee H., Lee } \\
\text { M.-K., Lee H., } \\
\text { Jang H. (2020) }\end{array}$ & $\begin{array}{l}\text { Development of a } \\
\text { Living Lab for a } \\
\text { Mobile-Based Health } \\
\text { Program for } \\
\text { Korean-Chinese } \\
\text { Working Women in } \\
\text { South Korea: Mixed } \\
\text { Methods Study }\end{array}$ & $\begin{array}{l}\text { Living lab in Health } \\
\text { care industry }\end{array}$ & $\begin{array}{l}\text { Develop a living lab for } \\
\text { a mobile-based health } \\
\text { (LL Health) program } \\
\text { focused on improving } \\
\text { the physical activity } \\
\text { and cultural adaptation } \\
\text { of female workers. }\end{array}$ & $\begin{array}{l}\text { How do the cultural } \\
\text { aspects and lifestyles } \\
\text { of women are } \\
\text { accommodated in the } \\
\text { entire process of LL } \\
\text { program development? }\end{array}$ \\
\hline Kim J., Moon I. (2020) & $\begin{array}{l}\text { A Study on Smart } \\
\text { Factory Construction } \\
\text { Method for } \\
\text { Efficient Production } \\
\text { Management in } \\
\text { Sewing Industry }\end{array}$ & $\begin{array}{l}\text { Living Lab in } \\
\text { manufacturing process }\end{array}$ & $\begin{array}{l}\text { Implication of } \\
\text { Living Lab on } \\
\text { production process }\end{array}$ & $\begin{array}{l}\text { Which elements of } \\
\text { Living Lab have strong } \\
\text { impact on production } \\
\text { capacity and } \\
\text { quality system? }\end{array}$ \\
\hline
\end{tabular}

Source: [37-40].

So, the above-mentioned authors' focus on the role of Living Lab in different market areas (production; construction, high-tech, etc.) but there is no concrete approach how to build effective and universal network using Living Lab landscape due to high diversity of start-up projects in Asian region.

This indicates that practical experts from the private sector with a proven track record can better provide the necessary support for start-ups within Living Lab approach.

Moreover, the difficulty of participating in government programs that usually require success discourages start-ups from participating. That's why it is necessary to discover the opinions of Korean practitioners about Living Lab development within UniversityIndustry cooperation. 


\section{Research Questions and Methodology}

\subsection{Research Goals and Limitations}

The main goal of this research is to evaluate the impact of living labs on the development of a domestic innovation ecosystem. The hypothesis is that different elements of living labs have direct and positive impacts on innovation ecosystem development. This hypothesis is supported by following concepts:

1. In order to expand Living Lab, its focus should not only be restricted to abstract discussion but also cover real-life related subjects such as current local issues or local economics as well as new technology, product or service which will eventually support everyday life of local residents or consumers. In this critical perspective, Living Lab execution model should be established that deals with practical and detailed life issues such as safety, residence, traffic, environment or health [40,41].

2. Kim in 2015 [41] reported that over the past decade, living labs have become an established part of local and regional innovation systems using a variety of methods and tools and focusing on a wide array of domains and themes. However, the experimental, learning-by-doing setup of living labs within various application domains in Korea and the lack of connection between living labs have led to a wide variation of approaches, results, and impacts. Furthermore, the economic logic and business model of living labs remain underdeveloped in the Korean market [42,43]. Therefore, as this innovation instrument matures, it is crucial to ensure that its main strength in terms of local embeddedness does not turn into a significant weakness in terms of the general applicability, validity, and robustness of living lab test results. Based on this evidence, the authors conclude that there is a need for an analytical approach enabling case-by-case customization of the collaboration model for every innovative product, service, or business model [44].

Three research questions were submitted during the survey to support the hypothesis:

1. How can an innovation system be developed with living laboratories?

2. How do living laboratories focus on start-up project development?

3. Could university-industry cooperation improves the innovation ecosystem using living labs?

There are some limitations of this research: It is based on a case study of only one country (South Korea); the period of the survey was one year (2020, a crisis year); and the scopes of the survey is focused on local programs of innovation system development and a competence model of the fourth industrial revolution.

\subsection{Research Methods}

The authors discuss the living lab as an element of the innovation ecosystem in the area of university-industry cooperation. Korea University was chosen for the field survey; this university has many projects with Samsung Corporation that are developed within the living laboratory process. The task of this survey was to analyze the impact of living laboratories (LLs) on the innovation ecosystem by evaluating the elements of LL using expert method interview.

The research methodology is based on quantitative data obtained in the public domain with a limited time frame. Also, employees of Korean high-tech companies and Korea University were interviewed, the impact of living labs on the innovation ecosystem was analyzed, and experts were involved (see Appendix A).

For the study, 30 experts (start-up project managers) from the Korea University living lab were selected using a simple random sample method. The selection process for experts was established and 4 requirements to expert competencies were assessed: (1) industry experience-at least 4 years; (2) project management practice-at least 2 projects during last 5 years; (3) age category-35-55 years old; (4) government-industry cooperation participant. 
The interview process was arranged based on the sample documents from each startup's business process. For example, a group of experts analyzed the set of LL elements and factors that have a strong impact on innovation ecosystem development processes.

\section{Survey and Results}

To achieve the purpose of this study, several steps of research were applied.

Step 1. For expertise, three types of experts from different fields were invited: one from industry (company representative), one from Korea University's smart factory department, and one a project manager (business or university representative). All of the experts were interviewed during the project "smart factory"; the length of the high-tech project was one year (2020). The experts were asked about the level of impact of elements of living labs on the quality of the innovation ecosystem in the high-tech industry (questionnaire list is presented in Appendix A). The survey was based on Korean market. Among main interview questions the positive and negative statements were submitted, for example:

- Resource management is an important element of living lab;

- Technology affects infrastructure and start-up development;

- Innovation ecosystem needs to be improved;

- Innovation ecosystem can be developed without living lab activities;

- Living lab needs support from government, etc.

The respondents had to evaluate each statement and make a consideration about its "true/false" attitude (evaluation scale is from 1 "strongly disagree" to 10 "strongly agree").

The living lab at Korea University consists of three management areas: material, production, and product (Figure 4). These processes are included in the integrated living lab (LL) process in the university-industry collaboration.

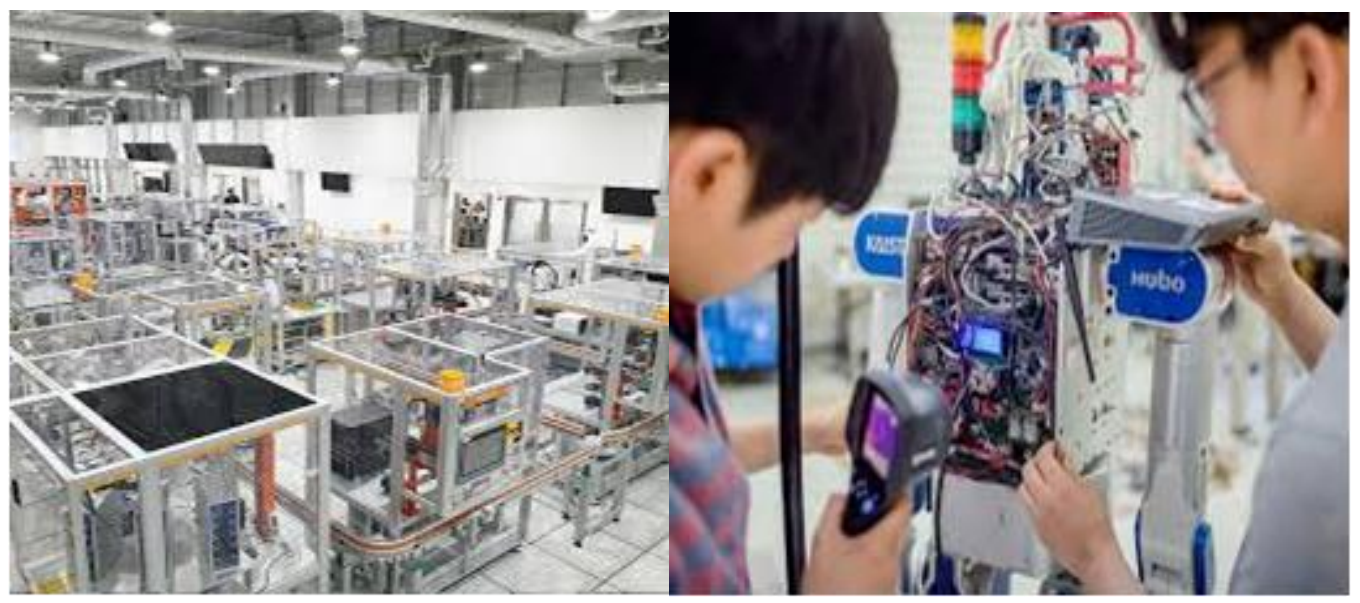

(a)

(b)

Figure 4. $(\mathbf{a}, \mathbf{b})$ Korea University smart learning factory as a part of living laboratory. Adapted from source: https://www.koreatechtoday.com/tag/living-lab/, accessed on 23 December 2020 [44].

Based on interview process results, mentioned in Appendix A (final comparative results are presented in Table A4), the most important 11 LL elements are investigated during first step of the interview process. They are: creating, developing and acquiring start-up; storing knowledge and ideas; challenging practice through collaboration; structural and communication capital (university-industry cooperation); sharing technology; infrastructure development; civic consciousness; human capital. It is interesting, that the experts' opinions were different at the 1st and final phases of the living Lab project, for example, most of the experts confirm in the beginning, that living Lab does have strong impact on Innovation system development. 30 experts from different groups evaluate the importance level of Living lab elements (minimum grade-less important, 5-maximum grade-the most 
important) and create the ranking list of them. Results from interview process are presented in Table 4. The results of testing the most important living lab components are as follows:

Table 4. LL elements' evaluation (expert method).

\begin{tabular}{|c|c|c|c|c|}
\hline LL Element & $\begin{array}{c}\text { Expert Group 1 } \\
\text { (Project Managers) }\end{array}$ & $\begin{array}{c}\text { Expert Group } 2 \\
\text { (University) }\end{array}$ & $\begin{array}{c}\text { Expert Group } 3 \\
\text { (Industry/Company } \\
\text { Representative Person) }\end{array}$ & $\begin{array}{l}\text { Average Weight of } \\
\text { Competence/Rank }\end{array}$ \\
\hline Creating and acquiring start-up & $4^{1}$ & 3 & 4 & $3.66 / 7$ \\
\hline Storing ideas/sources/knowledge & 4 & 5 & 5 & $4.66 / 1$ \\
\hline $\begin{array}{l}\text { Developing start-ups } \\
\text { (including support) }\end{array}$ & 4 & 5 & 3 & $4.0 / 6$ \\
\hline Challenging practice & 4 & 4 & 5 & $4.33 / 5$ \\
\hline Collaboration & 5 & 4 & 4 & $4.33 / 3$ \\
\hline Human capital & 1 & 1 & 1 & $1.0 / 10$ \\
\hline $\begin{array}{c}\text { Structural (organizational, } \\
\text { managerial) capital }\end{array}$ & 4 & 3 & 4 & $3.66 / 8$ \\
\hline Infrastructure development & 1 & 1 & 1 & $1.0 / 11$ \\
\hline Sharing technology & 5 & 4 & 5 & $4.66 / 2$ \\
\hline $\begin{array}{c}\text { Communication capital } \\
\text { (partnership) within } \\
\text { industry-university cooperation }\end{array}$ & 4 & 5 & 4 & $4.33 / 4$ \\
\hline Civic consciousness & 1 & 2 & 1 & $1.33 / 9$ \\
\hline
\end{tabular}

${ }^{1}$ Evaluation scale from 1 to 5 : 1 -minimum grade (less important), 5-maximum grade (the most important); this is average sum of expert group. Source: made by authors.

From this expert method we find that the most important LL elements for Korean market are: creating, developing and acquiring start-up; storing knowledge and ideas; challenging practice through collaboration; structural and communication capital (universityindustry cooperation); sharing technology. All of these competencies have average weight more than 3, 5 grades.

Step 2. During this step it is important to check the impact of each element of LL on innovation ecosystem's development outcome. Experts all together try to make a common decision (Table 5). By method of an expert evaluation of LL elements, fatten them on impact force for innovation ecosystem development (in expert's opinion). There are three areas of innovation ecosystem development in Korean market: development trough collaboration $\left(b_{1}\right)$; development trough infrastructure construction $\left(b_{2}\right)$; development through start-up forcing $\left(b_{3}\right)$.

Table 5. Impact of LL elements on innovation ecosystem (IE) development within industry-university cooperation (expert method).

\begin{tabular}{|c|c|c|c|c|}
\hline LL Element & $\begin{array}{l}\text { New Weight/Rank } \\
\text { (Transferred from } \\
\text { Previous Table) = a }\end{array}$ & $\begin{array}{l}\text { IE Development }= \\
\text { Collaboration }=b_{1}\end{array}$ & $\begin{array}{l}\text { IE Development }= \\
\text { Infrastructure }=b_{2}\end{array}$ & $\begin{array}{l}\text { IE Development }= \\
\text { Start-Up }=b_{3}\end{array}$ \\
\hline Storing ideas/sources/knowledge & $4.66=\mathrm{a}_{1}$ & $5^{1}$ & 6 & 3 \\
\hline Sharing technology & $4.66=\mathrm{a}_{2}$ & 7 & 3 & 5 \\
\hline Collaboration & $4.33=\mathrm{a}_{3}$ & 4 & 3 & 3 \\
\hline Communication capital (partnership) & & & & \\
\hline $\begin{array}{l}\text { within industry- } \\
\text { university cooperation }\end{array}$ & $4.33=\mathrm{a}_{4}$ & 6 & 4 & 7 \\
\hline Challenging practice & $4.33=a_{5}$ & 6 & 5 & 6 \\
\hline $\begin{array}{l}\text { Developing start-ups } \\
\text { (including support) }\end{array}$ & $4.0=\mathrm{a}_{6}$ & 3 & 4 & 2 \\
\hline Creating and acquiring start-up & $3.66=\mathrm{a}_{7}$ & 3 & 6 & 4 \\
\hline $\begin{array}{l}\text { Structural (organizational, } \\
\text { managerial) capital }\end{array}$ & $3.66=\mathrm{a}_{8}$ & 6 & 6 & 5 \\
\hline Weight of LL element (W)/ Rank ${ }^{2}$ & & 170.14 & 153.82 & 147.5 \\
\hline
\end{tabular}

${ }^{1}$ Evaluation scale-from 1 to 10: 1—minimum linkage between LL elements and innovation ecosystem (IE) development, 10—maximum linkage between LL elements and innovation ecosystem (IE) development. ${ }^{2}$ Calculation method: $\mathrm{W}$ (weight of LL element $)=\left(\mathrm{a}_{1} \times \mathrm{b}_{1}\right)+$ $\left(a_{2} \times b_{1}\right)+\ldots\left(a_{n} \times b_{1}\right)$. Source: made by authors. 
Based on the results from Table 5 we can see, that LL elements have the strongest impact on the first area of innovation ecosystem development (=development trough collaboration) within industry-university cooperation, because it has the highest rank.

When assessing the significance and influence of Living laboratory process on the innovation ecosystem development, the authors use a weighty factor model, and to assess the weight of this influence, the researcher use a standard start-up management model. It is important to determine the limitations of the application of this model, which are expressed in the fact that the values should be determined at the level of 0.95 . At the same time, indicators that do not fall within the range from 1.96 to -1.96 are the most significant. This means that the indicator falling within the range from 1.96 to -1.96 has no weight and is not considered in further evaluation. Figure 5 shows the impact of organizational components and their overall interactions on the production of knowledge capital.

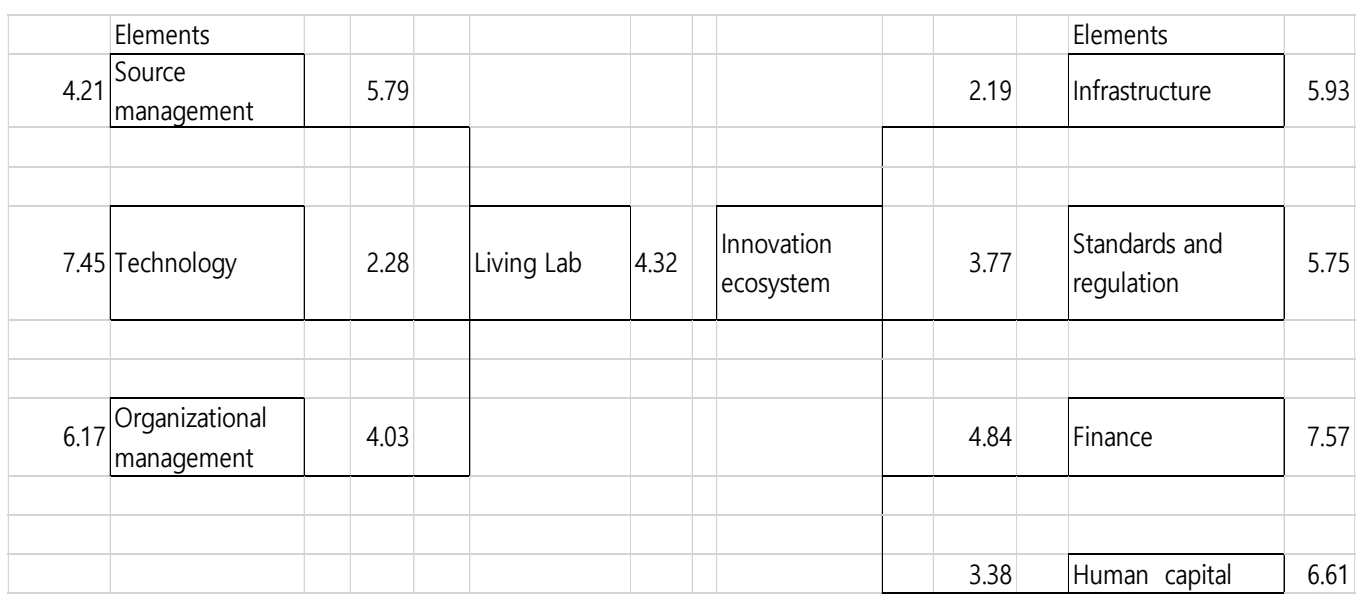

Figure 5. The model of Living laboratory effects on innovation ecosystem in standard mode. Chi-square $=42.87, \mathrm{df}=16$, $p$-value $=0.00005$, RMSEA $=0.039$. Source: made by authors.

The authors proposed to develop a semantic model that determines the various mutual influences of all these components on the final efficiency of innovation ecosystem in high-tech industry. The next step is to use a standard functional model, which makes it possible to assess the degree (weight) of the influence exerted by each parameter in the entire structure of relationships. Figure 6 shows the weights of the predicted relationships in this model.

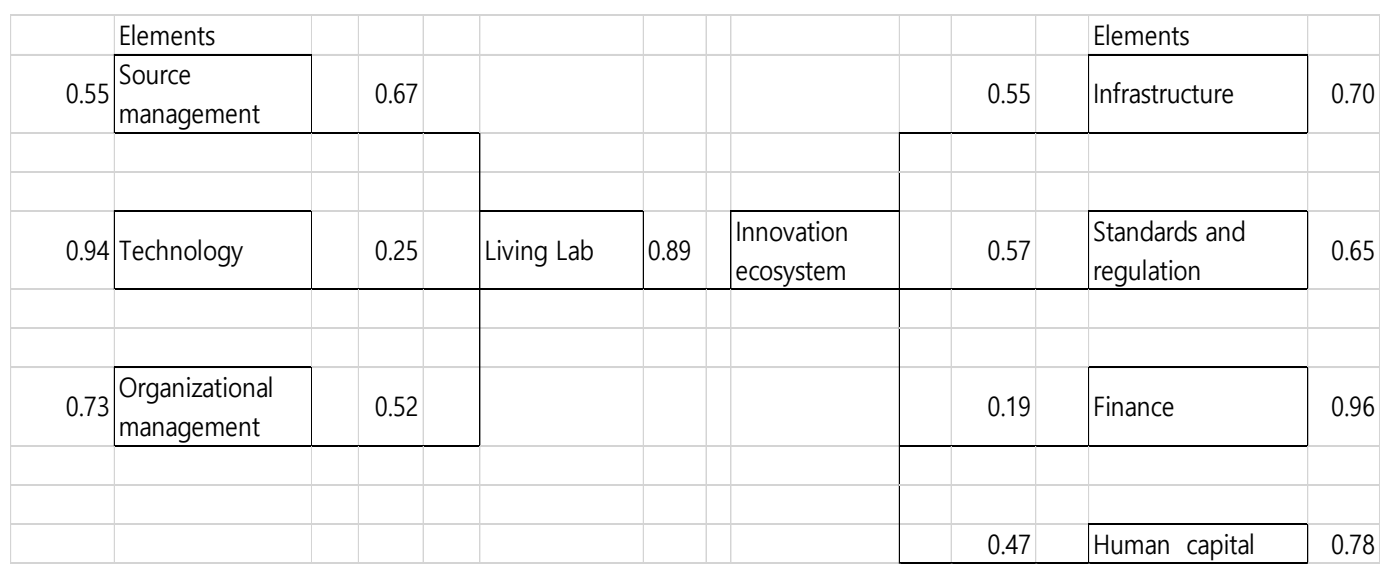

Figure 6. The model of Living laboratory effects on innovation ecosystem in standard mode. Chi-square $=42.87, \mathrm{df}=16$, $p$-value $=0.00005$, RMSEA $=0.039$. Source: made by authors.

According to the indicators presented in Table 6, one can judge the productivity of the research model. 
Table 6. Fittings of indexes of Living lab effects on innovation ecosystem.

\begin{tabular}{cccc}
\hline Indexes & Allowable Amount & Gained Numbers & Results \\
\hline $\begin{array}{c}\text { Proportion of Chi-square } \\
\text { to freedom degree }\end{array}$ & $\mathrm{X}_{2} / \mathrm{df}<3$ & 2.67 & Suitable fitting \\
\hline $\mathrm{P}_{\mathrm{i}}$ value & $p<0.05$ & 0.0005 & Suitable fitting \\
\hline $\begin{array}{c}\text { Root mean square of } \\
\text { approximate error (RMSEA) }\end{array}$ & $0.05<$ RMSEA $<0.08$ & 0.039 & Suitable fitting \\
\hline
\end{tabular}

Source: made by authors.

The model fit indices allow us to assess the degree of the model's suitability for assessing interrelated options, since the chi-squared ratio to the freedom index is 2.67 , which is less than the acceptable value of 3 ; also note that the root mean square value of the approximate error (0.039) is in the desired range of allowed values, and the Pi (0.0005) indicator shows a result that is less than the acceptable range, which is 0.05 . In accordance with the results of this model, the authors revealed a direct impact of Living lab on innovation ecosystem actions, since this influence has a value of 4.32 , which exceeds the value of 1.96. You then apply the standard model (Figure 6) to the study to assess the importance of the impact of organizational channels on the dissemination of knowledge in the start-up.

The authors further hypothesize how human source management, technology and organizational management (elements of Living lab) affect the quality of existence of innovation ecosystem (hypothesis). Thus, the researcher first applied a meaningful model to determine the degree to which each element of Living Lab influences management decisions in the innovation ecosystem. Then, a standard model was used that identified how each aspect affects the quality of the innovation ecosystem development. The authors assessed each of the research questions using separate approaches using an independent model. Since there are many scoring models, the organizer has set the limits of the study to select and apply only one scoring model (using factor analysis) [45]. The generalized results of the corresponding analysis of the data for these research questions are presented in Table 7. The data indicated in the table will help to further process the results and draw appropriate final conclusions.

Table 7. Results from assessing research questions.

\begin{tabular}{cc}
\hline $\begin{array}{c}\text { Hypothesis (H) and } \\
\text { Research Questions (RQs) }\end{array}$ & Path \\
\hline H & $\begin{array}{c}\text { Living lab has a significant } \\
\text { and positive impact on } \\
\text { management decisions in } \\
\text { innovation ecosystem }\end{array}$
\end{tabular}

Step of Research,
Where This Path Is Checked

Result

Based on the results from Table 5 we can see, that LL elements have the strongest impact on the first area of innovation ecosystem development (=development trough collaboration) within industry-university cooperation, because it has the highest rank.

From this expert method we find that the
most important LL elements for Korean
market are: creating, developing and
acquiring start-up; storing knowledge
and ideas; challenging practice through
collaboration; structural and
communication capital Confirmed
(university-industry cooperation);
sharing technology. All of these
competencies have average weight more
than 3, 5 grades (Table 4 ).

Could innovation system be developed with living laboratories?

RQ 1

Living lab has a significant innovation ecosystem 
Table 7. Cont.

Hypothesis (H) and
Research Questions (RQs)

Does university-industry cooperation improve innovation ecosystem using living labs?
RQ 2

RQ 3
Do living laboratories focus on start-up project development?
Step of Research, Where This Path Is Checked

Based on interview process results, mentioned in Appendix A, the most important 11 LL elements are investigated during first step of the interview process.

They are: creating, developing and acquiring start-up; storing knowledge and ideas; challenging practice through collaboration; structural and communication capital

Confirmed

(university-industry cooperation); sharing technology; infrastructure development; civic consciousness; human capital.

30 experts from different groups evaluate the importance level of Living lab elements (minimum grade-less important,

5-maximum grade-the most important) and create the ranking list of them.

Based on interview process results, mentioned in Appendix A, the most important 11 LL elements are investigated during first step of the interview process.

They are: creating, developing and acquiring start-up; storing knowledge and ideas; challenging practice through collaboration; structural and communication capital

(university-industry cooperation); sharing technology; infrastructure development; civic consciousness; human capital.

30 experts from different groups evaluate the importance level of Living lab elements (minimum grade-less important,

5-maximum grade-the most important) and create the ranking list of them.

Source: made by authors.

In accordance with the results obtained, it can be noted that the living lab approach directly affects the quality of the innovation ecosystem (Table 7). It is also obvious that an innovation system could be developed by implementing living laboratories. Living laboratories focus on start-up project development; university-industry cooperation improves the innovation ecosystem [45].

In this regard, the authors note that significant elements of living labs that influence the process of innovation ecosystem development are source management, organizational management, and the technology application process [46-48]. Confirmation of the stated hypothesis also justifies the formulation of important tasks to improve the process quality in living labs through various start-up support and development programs in order to optimize organizational design and overall strategy. Several components of living labs have been shown to be effective in the creation and development of innovation ecosystems. The results obtained do not contradict previously published studies in this area, and are also in agreement with the results of other authors [49,50]. It is also important to note the positive influence of all elements of living labs on the further development of innovation ecosystems in the literature of innovation management, which is consistent with the conclusions obtained by the authors. 


\section{Discussion}

Unfortunately, the living lab is still in the policy experiment stage in Korea. Considering this, this study explored the possibility of expanding the living lab as a means of developing an innovation ecosystem. The survey was made based on a university smart learning factory as an element of the living lab approach.

Carayannis et al. in 2016 [51] reported on the sustainable and dynamic interaction between all elements of a living laboratory and an innovation ecosystem, which can be carried out in accordance with models proven abroad such as the open innovation, triple helix, and quadruple helix models, which were discussed. There is also a quintuple helix model, which should be discussed in future research. Kolotyrina in 2019 [52] mentioned an additional tool to ensure the interaction of subjects of start-up entrepreneurship in an innovation ecosystem: business accelerators, which are associations of experienced executives who engage in leadership, mentoring, networking, and management projects. They provide office services and share knowledge and experience with employees of emerging companies, helping them overcome difficulties at the early stages of a product's life cycle [53].

Hubavem in 2019 [54] suggested that while the importance of using diverse approaches to the organization of living labs and their management models for sustainable development is evident, their flexibility, simplicity, and adaptability require further study in the face of the transformation of the Korean market. For example, the authors say that despite all of the obvious advantages of living labs, their implementation in the network of interactions between state, market, and university requires careful comprehensive planning and changes in regulatory market mechanisms. On the one hand, the high level of development of high technologies in Korea makes it possible to simplify some of the living lab management processes; for example, speeding up the transfer of technological service products and ensuring the protection of intellectual property [55]. However, these approaches are not so easy to implement in the market system of South Korea, which has had trouble for decades with the development of independent small businesses, and this is also a problem for the emergence of self-regulating mechanisms for the development and promotion of start-ups.

Known models of innovation management should not be considered as a panacea for solving all problems related to the sustainability of the innovation system in all contexts; that is, the limitations, primarily resource constraints, and the new cycle of development of the Korean economy in the post-crisis period should be noted [56]. Consequently, there is a need for accessible technology, information, and management platforms, which must be constantly updated based on industry standards of a competency model through which experience can be shared and disseminated across the network. A dynamic national research program, the results of which will be used in current and future projects in a continuous improvement cycle, will fuel such opportunities [57].

In this study, it was determined that the complex and multifactorial structure of the innovation network requires close attention to the living lab organization at the initial stage of its development in Korea. In the context of the development of new programs against the background of a global crisis (COVID-19), the Korean economy urgently needs a more standardized and robust common understanding of the development of innovation management mechanisms and processes. Living labs themselves provide a new flexible and more efficient environment for testing service offerings and innovations [58].

Korean companies are now increasingly focusing on adding value to collaborations that directly integrate the demands and creativity of clients, project participants, and other stakeholders. Korean companies see the living lab concept as a way to access globally dispersed knowledge and combine it with cutting-edge ICT solutions to create collaborative networks like living labs. Jorgen Rosted in 2017 [59] confirmed that these networks are paving the way for new types of dynamic, profitable, and positive relationships between the public sector, large companies, and sole proprietors. Various types and categories of innovations show that a special approach is recommended for each innovation process, 
including one that depends on the specifics of local market regulation. New ways of collaborating in innovation management show that groups and communities can pursue vastly different innovation programs and strategies. Therefore, the task of forming such mechanisms for managing the innovation ecosystem, including living labs, to help reduce such differences and enhance cooperation and synergistic effect of interaction, becomes urgent [60]. Such mechanisms can be effectively supported by living laboratories, since their dynamic infrastructure contributes to the increasing complexity of product development and, most importantly, allows them to quickly respond to changes in the external environment.

\section{Conclusions}

Korea is a representative country that has succeeded in economic development with a technology-supplied innovation strategy. However, in the new industry based on digital innovation such as AI and IOT in recent years, the use of creativity and experience of end users has become important, so a new innovation strategy from the perspective of end users is required. As a platform to promote the commercialization of technology and social use and diffuse, the introduction of Living Lab can be said to be an important task [61].

The authors take the position that the development of living labs in Korea is in the early stages due to a significant market regulation system based on the gap between the innovation system and market regulation. The purpose of this study, to investigate the influence of living labs on the innovation ecosystem of South Korea, was achieved, therefore the research was mainly focused on the innovation process within universityindustry cooperation. The presented expert method for analyzing the impact of living labs on the effectiveness of the innovation ecosystem is needed to rethink current innovation processes in the Korean high-tech market. The case study of a local university-industry environment was discussed, and the evaluation showed that there is a trend of supporting company innovation by specialized communities, including various networks and living lab structures.

The main hypothesis that different elements of living labs have direct and positive impacts on innovation ecosystem development was confirmed, and answers were found for the following research questions:

- How can an innovation system be developed with living laboratories?

- How do living laboratories focus on start-up project development?

- Could university-industry cooperation improves the innovation ecosystem using living labs?

Finally, the authors discussed different models of innovation management and usage in several living lab collaboration models. The focus is on the structures, objectives, and drivers of a collaborative innovation ecosystem and elements of living labs. The paper seeks to contribute to the existing knowledge of suitable service offerings, infrastructure, and management models of living labs in Korea. Living labs are typically centered on project-based idea creation and product testing services for companies.

For future research, it will be important to better understand the role of living labs in supporting innovation processes. In order to achieve this, living labs will need access to various user communities and partners that they can activate for projects or experiments as needed. For example, the comparison between Korea University Living Lab and other local Living Labs show the significant area of the research and future development according to local Innovative ecosystem (Table 8).

With this model, living labs can add more value to participating companies, and simultaneously, the relevance and robustness of the research will improve as required in order to effectively respond to fast evolving global markets and emerging socio-technoeconomic demand-side trends. 
Table 8. Comparison of Korea University Living Lab with other local Living Lab.

\begin{tabular}{|c|c|c|c|c|}
\hline Category & Bukchon Living Lab & $\begin{array}{l}\text { Seong-Daegol } \\
\text { Living Lab }\end{array}$ & Geonneoyu Project & $\begin{array}{l}\text { Korea University } \\
\text { Living Lab }\end{array}$ \\
\hline $\begin{array}{l}\text { Project background } \\
\text { and regional issue }\end{array}$ & $\begin{array}{l}\text { Commercialization of } \\
\text { IoT technology } \\
\text {-Introduction of Living } \\
\text { Lab as a means of } \\
\text { investigate and solve } \\
\text { issues in cities }\end{array}$ & $\begin{array}{l}\text { Consciousness of crisis } \\
\text { was raised due to } \\
\text { Fukushima Daiichi } \\
\text { nuclear disaster and } \\
\text { blackout crisis } \\
\text { Civic consciousness has } \\
\text { been raised about } \\
\text { energy conversion }\end{array}$ & $\begin{array}{l}\text { Expansion of user } \\
\text { participation in process } \\
\text { of innovating } \\
\text { scientific technology } \\
\text { Increased demand on } \\
\text { solving everyday } \\
\text { life-related problems }\end{array}$ & $\begin{array}{l}\text { Expansion of } \\
\text { Industry-University } \\
\text { cooperation in process } \\
\text { of innovating } \\
\text { scientific technology } \\
\text { Increased demand on } \\
\text { solving everyday } \\
\text { life-related problems }\end{array}$ \\
\hline Project Objective & $\begin{array}{l}\text { Solving issues of city } \\
\text { with IoT and promote } \\
\text { convenience of tourists }\end{array}$ & $\begin{array}{l}\text { Finding technological } \\
\text { alternative for } \\
\text { self-sufficient energy } \\
\text { and related experiments }\end{array}$ & $\begin{array}{l}\text { Solution of residents' } \\
\text { discomfort and } \\
\text { enhanced convenience } \\
\text { by using steeping stones }\end{array}$ & $\begin{array}{l}\text { Solution of high-tech } \\
\text { products market } \\
\text { implementation }\end{array}$ \\
\hline $\begin{array}{l}\text { Governance } \\
\text { Infrastructure }\end{array}$ & $\begin{array}{l}\text { Government-provided } \\
\text { infrastructure (Free } \\
\text { access to Wi-fi network } \\
\text { and public information) }\end{array}$ & $\begin{array}{l}\text { Institutional, financial } \\
\text { support for civil } \\
\text { society-driven } \\
\text { movement of } \\
\text { energy conversion }\end{array}$ & $\begin{array}{l}\text { Civil society finds the } \\
\text { problem by itself and } \\
\text { suggests an alternative }\end{array}$ & $\begin{array}{l}\text { Government } \\
\text { control system }\end{array}$ \\
\hline
\end{tabular}

Source: made by authors, based on [62].

Author Contributions: Conceptualization, S.-K.L.; Data curation, O.A.S.; Investigation, S.-K.L.; Methodology, O.A.S.; Project administration, O.A.S.; Resources, S.-K.L. Both authors have read and agreed to the published version of the manuscript.

Funding: This research was funded by KOREATECH research fund 2021.

Institutional Review Board Statement: Not applicable.

Informed Consent Statement: Not applicable.

Data Availability Statement: Not applicable.

Conflicts of Interest: The authors declare no conflict of interest.

Appendix A

Table A1. Expert interview list example.

\begin{tabular}{|c|c|c|c|c|c|c|c|c|c|c|}
\hline Statement & $\begin{array}{c}1 \\
\text { Strongly } \\
\text { Disagree }\end{array}$ & 2 & 3 & 4 & 5 & 6 & 7 & 8 & 9 & $\begin{array}{c}10 \\
\text { Strongly } \\
\text { Agree }\end{array}$ \\
\hline \multicolumn{11}{|l|}{$\begin{array}{l}1 \text { Living lab has strong positive impact on } \\
\text { innovation ecosystem development }\end{array}$} \\
\hline \multicolumn{11}{|l|}{2 Living lab needs support from government } \\
\hline \multicolumn{11}{|l|}{3 Innovation ecosystem needs to be improved } \\
\hline \multicolumn{11}{|l|}{$\begin{array}{l}4 \text { Resource management is an important } \\
\text { element of living lab }\end{array}$} \\
\hline \multicolumn{11}{|l|}{$\begin{array}{l}5 \text { Organizational management } \\
\text { is an important part of living lab }\end{array}$} \\
\hline \multicolumn{11}{|l|}{$\begin{array}{l}6 \text { Financial sources of innovation ecosystem } \\
\text { have impact on living lab life cycle }\end{array}$} \\
\hline \multicolumn{11}{|l|}{$\begin{array}{l}7 \text { Technology affects infrastructure and } \\
\text { start-up development }\end{array}$} \\
\hline $\begin{array}{l}8 \text { Legal regulations and standards are } \\
\text { not important for living labs }\end{array}$ & & & & & & & & & & \\
\hline
\end{tabular}


Table A1. Cont.

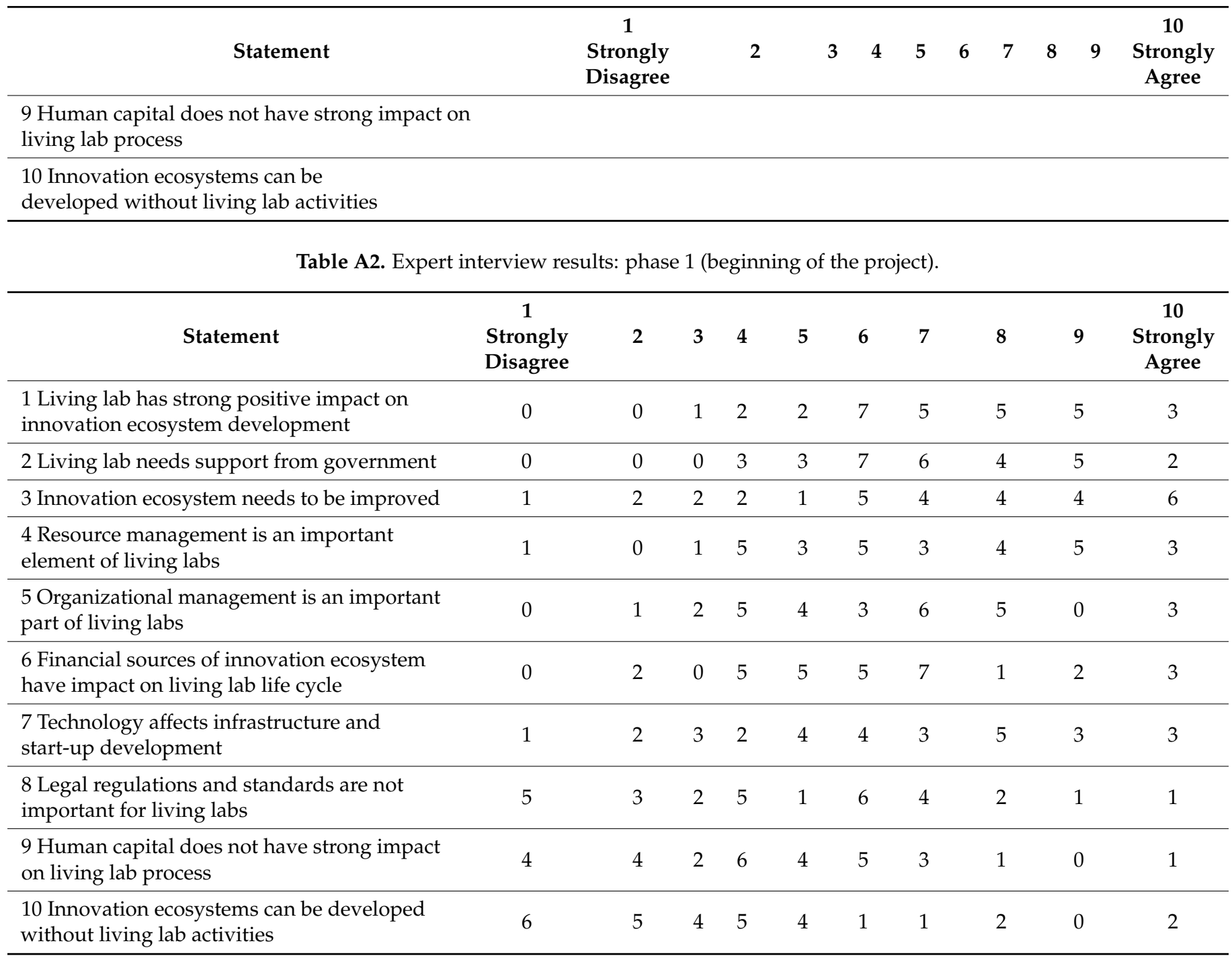

Table A3. Expert interview results: phase 2 (final step of the project).

\begin{tabular}{|c|c|c|c|c|c|c|c|c|c|c|}
\hline Statement & $\begin{array}{c}1 \\
\text { Strongly } \\
\text { Disagree }\end{array}$ & 2 & 3 & 4 & 5 & 6 & 7 & 8 & 9 & $\begin{array}{c}10 \\
\text { Strongly } \\
\text { Agree }\end{array}$ \\
\hline $\begin{array}{l}1 \text { Living lab has strong positive impact on } \\
\text { innovation ecosystem development }\end{array}$ & 0 & 0 & 1 & 1 & 1 & 7 & 7 & 5 & 5 & 3 \\
\hline 2 Living lab needs support from government & 0 & 0 & 0 & 1 & 3 & 7 & 6 & 4 & 5 & 4 \\
\hline 3 Innovation ecosystem needs to be improved & 1 & 0 & 0 & 2 & 3 & 5 & 6 & 4 & 4 & 6 \\
\hline $\begin{array}{l}4 \text { Resource management is an important } \\
\text { element of living labs }\end{array}$ & 0 & 0 & 0 & 5 & 3 & 5 & 5 & 4 & 5 & 3 \\
\hline $\begin{array}{l}5 \text { Organizational management is an important } \\
\text { part of living labs }\end{array}$ & 0 & 1 & 1 & 3 & 4 & 4 & 6 & 5 & 2 & 3 \\
\hline $\begin{array}{l}6 \text { Financial sources of innovation ecosystem } \\
\text { have impact on living lab life cycle }\end{array}$ & 0 & 0 & 0 & 5 & 5 & 5 & 7 & 3 & 2 & 3 \\
\hline $\begin{array}{l}7 \text { Technology affects infrastructure and } \\
\text { start-up development }\end{array}$ & 1 & 0 & 0 & 2 & 4 & 4 & 3 & 5 & 6 & 5 \\
\hline
\end{tabular}


Table A3. Cont.

\begin{tabular}{|c|c|c|c|c|c|c|c|c|c|c|}
\hline Statement & $\begin{array}{c}1 \\
\text { Strongly } \\
\text { Disagree }\end{array}$ & 2 & 3 & 4 & 5 & 6 & 7 & 8 & 9 & $\begin{array}{c}10 \\
\text { Strongly } \\
\text { Agree }\end{array}$ \\
\hline $\begin{array}{l}8 \text { Legal regulations and standards are not } \\
\text { important for living labs }\end{array}$ & 7 & 3 & 2 & 5 & 1 & 6 & 2 & 2 & 1 & 1 \\
\hline $\begin{array}{l}9 \text { Human capital does not have strong impact } \\
\text { on Living lab process }\end{array}$ & 6 & 4 & 2 & 6 & 4 & 5 & 2 & 1 & 0 & 0 \\
\hline $\begin{array}{l}10 \text { Innovation ecosystems may be developed } \\
\text { without living lab activities }\end{array}$ & 8 & 5 & 4 & 5 & 4 & 0 & 0 & 2 & 2 & 0 \\
\hline
\end{tabular}

Table A4. Expert interview results: comparison of results from phase 1 and 2.

\begin{tabular}{|c|c|c|c|c|}
\hline Statement & $\begin{array}{c}1 \\
\text { Strongly Disagree } \\
\text { Phase } 2 \\
\end{array}$ & $\begin{array}{c}1 \\
\text { Strongly Disagree } \\
\text { Phase } 1 \\
\end{array}$ & $\begin{array}{c}10 \\
\text { Strongly Agree } \\
\text { Phase } 2\end{array}$ & $\begin{array}{c}10 \\
\text { Strongly Agree } \\
\text { Phase } 1\end{array}$ \\
\hline $\begin{array}{l}1 \text { Living lab has strong positive impact on } \\
\text { innovation ecosystem development }\end{array}$ & 0 & 0 & 3 & 3 \\
\hline $\begin{array}{l}2 \text { Living lab needs } \\
\text { support from government }\end{array}$ & 0 & 0 & 4 & 2 \\
\hline $\begin{array}{l}3 \text { Innovation ecosystem } \\
\text { needs to be improved }\end{array}$ & 1 & 1 & 6 & 6 \\
\hline $\begin{array}{l}4 \text { Resource management is an important } \\
\text { element of living labs }\end{array}$ & 0 & 1 & 3 & 3 \\
\hline $\begin{array}{l}5 \text { Organizational management is an } \\
\text { important part of living labs }\end{array}$ & 0 & 0 & 3 & 3 \\
\hline $\begin{array}{l}6 \text { Financial sources of innovation } \\
\text { ecosystem have impact on } \\
\text { living lab life cycle }\end{array}$ & 0 & 0 & 3 & 3 \\
\hline $\begin{array}{l}7 \text { Technology affects infrastructure and } \\
\text { start-up development }\end{array}$ & 1 & 1 & 5 & 3 \\
\hline $\begin{array}{l}8 \text { Legal regulations and standards are not } \\
\text { important for living labs }\end{array}$ & 7 & 5 & 1 & 1 \\
\hline $\begin{array}{l}9 \text { Human capital does not have strong } \\
\text { impact on Living lab process }\end{array}$ & 6 & 4 & 0 & 1 \\
\hline $\begin{array}{l}10 \text { Innovation ecosystems may be } \\
\text { developed without living lab activities }\end{array}$ & 8 & 6 & 0 & 2 \\
\hline
\end{tabular}

\section{References}

1. Lee, S.; Lee, H.; Lee, C. Open innovation at the national level: Towards a global innovation system. Technol. Forecast. Soc. Chang. 2020, 151, 119842. [CrossRef]

2. Sung, C. Innovation, Competitiveness, and Growth: Korean Experiences. Annual World Bank Conference on Development Economics, Global, The International Bank for Reconstruction and Development, The World Bank. 2020, pp. 337-340. Available online: http:/ / www.rrojasdatabank.info/wbdevecon10-22.pdf (accessed on 23 October 2020).

3. Geiger, R.; Sá, C. Tapping the Riches of Science: Universities and the Promise of Economic Growth; Harvard: Cambridge, MA, USA, 2013; pp. 378-409.

4. Brynjolfsson, E.; McAfee, A. The Second Machine Age: Work, Progress and Prosperity in a Time of Brilliant Technologies; W.W. Norton \& Company: New York, NY, USA, 2014; pp. 23-34.

5. Taylor, S.; Hansen, H. Finding form: Looking at the field of organizational aesthetics. J. Manag. Stud. 2015, 42, 1211-1231. [CrossRef]

6. Cresson, E. Towards a Knowledge-Based Europe; Lecture by Mrs. Edith Cresson at the London School of Economics and Political Science; European Commission: Brussels, Belgium, 2018; pp. 34-41.

7. Kim, G. The concept of the third level for South Korea, Responsible innovation system. Policy Rev. 2018, 2, 23-48.

8. Seong, J.; Han, K.; Jeong, S. A Case Study on Korean Living Labs for Local Problem-Solving. J. Sci. Technol. Stud. 2016, 16, 65-98. 
9. Global Innovation Index 2019. Available online: https://thegedi.org/ (accessed on 16 September 2020).

10. Rothschild, M. Bionomics: Economy as Ecosystem; Henry Holt and Company: New York, NY, USA, 1990; pp. 67-123.

11. Morrar, R.; Arman, H.; Mousa, S. The Fourth Industrial Revolution (Industry 4.0): A Social Innovation Perspective. Technol. Innov. Manag. Rev. 2017, 7, 12-20. [CrossRef]

12. Buhr, D. Social Innovation Policy for Industry 4.0; Eberhard Karls University of Tübingen: Tübingen, Germany, 2017; pp. 45-121.

13. Friesen, E. The World Economic Forum and Transnational Networking; Emerald Publishing Limited: Bingley, UK, $2020 ;$ pp. 133-161.

14. Compagnucci, L.; Spigarelli, F.; Coelho, J.; Duarte, C. Living Labs and user engagement for innovation and sustainability. J. Clean. Prod. 2021, 289, 125-721. [CrossRef]

15. Leminen, S.; Westerlund, M.; Nyström, A.; Kortelainen, M. The Effect of Network Structure on Radical Innovation in Living Labs. J. Bus. Ind. Mark 2016, 31, 743-757. [CrossRef]

16. Schuurman, D.; Herregodts, A.-L.; Georges, A.; Rits, O. Innovation Management in Living Lab Projects: The Innovatrix Framework. Technol. Innov. Manag. Rev. 2019, 9, 63-73. [CrossRef]

17. Wessner, C.W. Innovation Policies for the 21st Century; Report of a Symposium; The National Academies Press: Washington, DC, USA, 2015; pp. 34-39.

18. Joel, R. Troy University/Building an IT Economy: South Korean Science and Technology Policy. Technology Innovation. 2018, Volume 19, pp. 1-9. Available online: https:/ /www.brookings.edu/wp-content/uploads/2016/06/CTI_19-_Korea_Tech_Paper_ Formatted.pdf (accessed on 12 December 2020).

19. What Is a Living Lab? About Us, ENoLL. Available online: http:/ / www.openlivinglabs.eu/aboutus (accessed on 22 November 2020).

20. Leminen, S.; Westerlund, M.; Nyström, A. Living Labs as Open Innovation Networks. Technol. Innov. Manag. Rev. 2012, 9, 6-11. [CrossRef]

21. Feurstein, K.; Hesmer, A.; Hribernik, K.A.; Thoben, K.D.; Schumacher, J. Living Labs: A new development strategy. In European Living Labs-A New Approach for Human Centric Regional Innovation; Wissenschaftlicher Verlag: Berlin, Germany, 2008; pp. 1-4.

22. Baccarne, B.; Logghe, S.; Veeckman, C.; Schuurman, D. Why collaborate in long-term innovation research? An exploration of user motivations in Living Labs. In Proceedings of the 4th ENoLL Living Lab Summer School 2013, Manchester, UK, 27-30 August 2013; European Network of Living Labs: Brussels, Belgium, 2013.

23. Leshakova, N. State regulation of innovative development of the Republic of Korea. Russ. J. Innov. Econ. 2017, 7, 161-174.

24. Luppicini, R. Ethical Impact of Technological Advancements and Applications in Society; Information Science Reference: Hershey, PA, USA, 2018; pp. 3-12.

25. Lee, C. Features of corporate governance and the role in the development of the national economy. Bull. Peoples' Friendsh. Univ. Russ. Ser. Econ. 2019, 4, 27-37. (In Russian)

26. Etzkowitz, H.; Leydesdorff, L. The dynamics of innovation: From national systems and 'Mode 2' to a triple helix of universityindustry-government relations. Res Policy 2000, 29, 109-123. [CrossRef]

27. Arnkil, R.; Järvensivu, A.; Koski, P.; Piirainen, T. Exploring Quadruple Helix. Outlining User-Oriented Innovation Models, Final Report on Quadruple Helix Research for the CLIQ Project, Tampere. 2016. Available online: http://uta32-kk.lib.helsinki.fi/ bitstream/handle/10024/65758/978--951--44--8209--0.pdf?sequence=1 (accessed on 2 December 2020).

28. Leydesdorff, L. The Knowledge-Based Economy and the Triple Helix Model. Annu. Rev. Inf. Sci. Technol. 2012, 44, 365-417. [CrossRef]

29. Galvao, A.; Mascarenhas, C.; Marques, C.; Ferreira, J.; Ratten, V. Triple helix and its evolution: A systematic literature review. J. Sci. Technol. Policy Manag. 2019, 10, 812-833. [CrossRef]

30. Etzkowitz, H.; Leydesdorff, L. The Triple Helix-University-Industry-Government Relations: A Laboratory for Knowledge Based Economic Development; SSRN: Rochester, NY, USA, 1995; SSRN 2480085.

31. Etzkowitz, H.; Leydesdorff, L. The endless transition: A “Triple Helix" of university-industry-government relations, introduction to a theme issue. Minerva 1998, 36, 203-218. [CrossRef]

32. Carayannis, E.; Campbell, D. Mode 3 and Quadruple Helix: Toward a 21st century fractal innovation ecosystem. Int. J. Technol. Manag. 2015, 46, 201-234. [CrossRef]

33. The Triple Helix Concept; Stanford University Triple Helix Research Group: Stanford, CA, USA, 2017 ; pp. 45-67.

34. Park, H.W. Transition from the Triple Helix to N-Tuple Helices? An interview with Elias G. Carayannis and David F. J. Campbell. Scientometrics 2014, 99, 203-207. [CrossRef]

35. Kwon, K. Emergence of Research and Entrepreneurial Activities of Korean Universities. In Proceedings of the Conference on University-Industry Linkages and Economic Performance, Seoul, Korea, 27-29 February 2009.

36. Lee, J. The Republic of Korea's Economic Growth and Catch-Up: Implications for the People's Republic of China. Working Paper Series ADBI. 2016. No. 571. pp. 28-30. Available online: https://www.adb.org/sites/default/files/publication/183353 /adbiwp571.pdf (accessed on 1 November 2020).

37. Han, J.; Kim, K. Enhancing Innovation Platform: Bitgaram Innocity Gwangju Using ICT in Korea. Asian Res. Policy 2015, 6, 13-26.

38. Cho, E. Transforming a Neighborhood into a Living Laboratory for Ur-ban Social Innovation: A Com-parative Case Study of Urban Living Labs. In Cross-Cultural Design. Applications in Cultural Heritage, Creativity and Social Development; Springer: Cham, Switzerland, 2018. [CrossRef]

39. Kim, Y.; Lee, H.; Lee, M.-K.; Lee, H.; Jang, H. Development of a Living Lab for a Mobile-Based Health Program for Korean-Chinese Working Women in South Korea: Mixed Methods Study. J. Med. Interdiscip. Res. 2020, 8, e15359. [CrossRef] 
40. Kim, J.; Moon, I. A Study on Smart Factory Construction Method for Efficient Production Management in Sewing Industry. J. Inf. Commun. Converg. 2020, 18, 61-68.

41. Kim, E. The impact of family ownership and capital structures on productivity performance of Korean manufacturing firms: Corporate governance and the «chaebol problem». J. Jpn. Int. Econ. 2015, 20, 209-233. Available online: https: //www.researchgate.net/publication/222672874_The_impact_of_family_ownership_and_capital_structures_on_productivity_ performance_of_Korean_manufacturing_firms_Corporate_governance_and_the_chaebol_problem (accessed on 12 October 2020). [CrossRef]

42. Frank, C.; Kim, K.; Westphal, L. Foreign Trade Regimes and Economic Development: South Korea; National Bureau of Economic Research: New York, NY, USA, 1995; pp. 23-45.

43. Abatecola, G.; Mandarelli, G.; Poggesi, S. The personality factor: How top management teams make decisions. A literature review. J. Manag. Gov. 2013, 17, 1073-1100. [CrossRef]

44. KoreaTechToday. Available online: https://www.koreatechtoday.com/tag/living-lab/ (accessed on 12 December 2020).

45. Preuveneers, D.; Ilie-Zudor, E. The intelligent industry of the future: A survey on emerging trends, research challenges and opportunities in Industry 4.0. J. Ambient. Intell. Smart Environ. 2017, 9, 287-298. [CrossRef]

46. Wise, E.; Høgenhaven, C. User-Driven Innovation, Context and Cases in the Nordic Region; Nordic Innovation Centre: Oslo, Norway, 2018; pp. 56-102.

47. Schuh, G.; Potente, T.; Wesch-Potente, C.; Weber, A.; Prote, J. Collaboration Mechanisms to increase Productivity in the Context of Industrie 4.0. In Proceedings of the 19th Robust Manufacturing Conference (CIRP), Bremen, Germany, 7-9 July 2014; pp. 51-56.

48. Mosconi, M. The New European Industrial Policy; Routledge: London, UK, 2015; ISBN 9781315761756.

49. Buguin, J.; Dobbs, R.; Bisson, P.; Marrs, A. Disruptive Technologies: Advances that Will Transform Life, Business, and the Global Economy; McKinsey Global Institute: San Francisco, CA, USA, 2019; pp. 67-99.

50. Guidelines for Living Labs in Climate Service, EU MACS. Available online: http:/ / eu-macs.eu/ (accessed on 9 March 2019).

51. Carayannis, E.; Campbell, D. Mode 3 Knowledge Production in Quadruple Helix Innovation Systems; Springer Briefs in Business; Springer: New York, NY, USA, 2016; pp. 5-9.

52. Kolotyrina, E. Specific Features of Innovation System Formation of The Republic of Korea. Bull. Peoples' Friendsh. Univ. Russ. Ser. Econ. 2019, 2, 96-105. (In Russian)

53. Schuurman, D.; De Moor, K.; De Marez, L.; Evens, T. Living Lab research approach for mobile TV. Telemat. Inform. 2011, 28, 271-282. [CrossRef]

54. Hubavem, G. Open Innovation 4.0, Digital Single Market; European Commission: Brussels, Belgium, 2019 ; pp. 56-78.

55. Hossain, M.; Leminen, S.; Westerlund, M. A Systematic Review of Living Lab Literature. J. Clean. Prod. 2019, 213, 976-988. [CrossRef]

56. Schuurman, D.; de Marez, L.; Ballon, P. Living Labs: A Systematic Literature Review. In Proceedings of the Open Living Lab Days, Istanbul, Turkey, 25-28 August 2015.

57. Schwab, K. The Fourth Industrial Revolution; World Economic Forum: New York, NY, USA, 2014; pp. 34-52.

58. Shvetsova, O. Technology learning in automobile industry: Comparative study between Korean and Thai Companies. Open Transp. J. 2019, 13, 236-249. [CrossRef]

59. Rosted, J.; Lau, T.; Hogenhaven, C.; Johansen, P. Concept Design: How to Solve Complex Challenges of Our Time; Mc Afee: San Jose, CA, USA, 2017; pp. 67-108.

60. Kim, M.; Kim, P.; Yoon, J. Living Lab as a Industrial Platform. Ind. Eng. Mag. 2020, 27, 38-45.

61. Seung, J.; Song, W.; Kim, J.; Jung, S.; Han, K. Designing Living Labs for Technology Commercialization. STEPI Insight 2016, 198,1 1-39.

62. Cha, H. Living Labs based on IT utilization and development of local community. Int. J. Internet Broadcasting Commun. 2018, 10, 31-36. 